\title{
FAKTOR YANG MEMPENGARUHI AUDIT DELAY
}

\author{
Dwi Puryati \\ Dwi.puryati@yahoo.com \\ STIE Ekuitas Bandung
}

\begin{abstract}
Go public Companies are required to publish their financial reporting that have been audited by an external auditor in accordance with the specified time. However in practice there are still companies that are late in submitting financial reporting. This research aims to examine the effect of audit tenur, audit opinion and size company to audit delay in manufacture companies listed in Indonesia Stock Exchange in 2016-2018. The population in this research are manufacture companies that listed on the Indonesia Stock Exchange in 2016-2018 with total number of 108 companies. The sample was selected by random sample with the number of samples calculated by the Solvin formula, and obtained the result of 85 samples. The data analysis technique is used simultaneously and partially hypothesis test. The results of the study show that simultaneously audit tenure, audit opinion and company size have a significant effect on audit delay. While partially audit tenure and audit opinion have a significant effect on audit delay, and company size does not significant effect on audit delay.
\end{abstract}

\section{Keywords: Audit Tenure, Audit Opinion, Company Size, Audit Delay}

\section{PENDAHULUAN}

\section{Latar Belakang Penelitian}

Setiap perusahaan wajib menyusun laporan keuangan yang merupakan suatu penyajian terstruktur dari posisi keuangan dan kinerja suatu entitas (Ikatan Akuntan Indonesia, 2017). Laporan keuangan merupakan laporan tertulis yang menyampaikan kegiatan bisnis dan kinerja keuangan suatu perusahaan. Perusahaan yang sudah go public wajib untuk melaporkan dan mempublikasikan laporan keuangan. Di Indonesia laporan keuangan yang disusun perusahaan harus sesuai dengan Standar Akuntansi Keuangan (SAK) yang berlaku dan diaudit oleh Akuntan Publik atau Auditor independen yang terdaftar di Otoritas Jasa Keuangan (OJK). Laporan keuangan harus dapat menyajikan informasi secara handal, relevan, dapat diperbandingkan, dapat dipahami, akurat dan tepat waktu. Ketepatan waktu pelaporan keuangan merupakan karakteristik utama dalam laporan keuangan, sehingga laporan keuangan perlu disampaikan secara tepat waktu agar dapat memberikan manfaat untuk pengambilan keputusan bagi penggunanya (Carslaw \& Kaplan, 1991).

Perusahaan yang sudah go public mempunyai kewajiban untuk menerbitkan laporan keuangan yang diaudit oleh akuntan yang terdaftar di OJK paling lambat pada akhir bulan keempat setelah tanggal laporan keuangan tahunan. Peraturan OJK Nomor 29/POJK.04/2016 tentang Laporan Tahunan Emiten atau Perusahaan Publik pasal 7 ayat (1) menyatakan bahwa emiten atau perusahaan publik wajib menyampaikan laporan tahunan kepada OJK paling lambat pada akhir bulan keempat (120 hari) setelah tahun buku berakhir. Apabila ada pihak yang melanggar peraturan OJK akan dikenakan sanksi berupa peringatan tertulis, denda berupa kewajiban untuk membayar sejumlah uang tertentu, pembatasan kegiatan usaha, pembekuan kegiatan usaha, pencabutan izin usaha, pembatalan persetujuan, dan pembatalan pendaftaran. Namun demikian pada kenyataannya, perusahaan yang sudah go public masih ada yang menyampaikan laporan keuangan yang sudah diaudit terlambat 
dari batas waktu yang sudah ditetapkan. Jumlah perusahaan yang terlambat menyampaikan laporan keuangan dari tahun 2016 sampai dengan 2018 mengalami fluktuasi. Pada tahun 2016 ada 63 perusahaan dari total perusahaan sejumlah 555 atau 11,35\%, pada tahun 2017 ada 70 perusahaan dari 555 perusahaan atau 12,61\%, dan tahun 2018 ada 51 perusahaan dari 619 perusahaan atau 8,24 $\%$. Pada bulan Juli 2019, BEI menjatuhkan suspensi dan perpanjangan suspense kepada sepuluh perusahaan dikarenakan belum menyampaikan laporan keuangan audit per 31 Desember 2018 dan atau belum melakukan pembayaran denda atas keterlambatan penyampaian laporan keuangan. Perusahaan yang mendapatkan suspensi yaitu PT Apexindo Pratama Duta Tbk (APEX), PT Bakrieland Development Tbk (ELTY), PT Sugih Energy Tbk (SUGI), PT Nipress Tbk (NIPS). Sementara emiten yang diperpanjang suspensinya adalah PT Tiga Pilar Sejahtera Food Tbk (AISA), PT Borneo Lumbung Energi \& Metal Tbk (BORN), PT Golden Plantation Tbk (GOLL), PT Sigmagold Inti Perkasa Tbk (TMPI), PT Cakra Mineral Tbk (CKRA), dan PT Evergreen Invesco Tbk (GREN).(CNBC Indonesia, 2019).

Audit delay akan menimbulkan reaksi negatif dari pelaku pasar rmodal, dan juga dapat membuat citra perusahaan menjadi buruk. Menurut Ashton Robert H, et. al (1987) "Audit delay is the length of time from a company's fiscal year end to the date of the auditor's report". Audit delay dapat merugikan perusahaan baik itu dari segi finansial maupun tingkat relevansi informasi laporan keuangan. Audit delay dapat mempengaruhi tingkat relevansi informasi dari sebuah laporan keuangan, karena semakin lama waktu dalam melakukan audit maka tingkat relevansi informasinya dapat diragukan. Lamanya proses penyelesaian audit dapat mempengaruhi audit delay dalam penyampaian laporan keuangan audit sehingga dapat berdampak buruk pada reaksi pasar dan menyebabkan ketidakpastian dalam pengambilan keputusan ekonomi. Keterlambatan publikasi laporan keuangan juga bisa menjadi indikasi adanya masalah dalam laporan keuangan perusahaan tersebut, sehingga auditor membutuhkan waktu yang lebih lama dalam melakukan proses penyelesaian auditnya. Tenur Audit adalah jangka waktu sebuah kantor akuntan publik melakukan perikatan terhadap kliennya dalam memberikan jasa audit laporan keuangan (Praptika dan Rasmini, 2016). Peraturan OJK Nomor 13/POJK.03/2017 tentang Penggunaan Jasa Akuntan Publik dan Kantor Akuntan Publik dalam Kegiatan Jasa Keuangan pasal 16 ayat 1 menyatakan bahwa pihak yang melaksanakan kegiatan jasa keuangan wajib membatasi penggunaan jasa audit atas informasi keuangan historis tahunan dari akuntan publik yang sama paling lama untuk periode audit selama 3 (tiga) tahun buku pelaporan secara berturut-turut. Seorang auditor yang sudah pernah melakukan audit pada suatu perusahaan akan memahami karakteristik dan dapat merancang program audit dengan baik sehingga auditor tidak membutuhkan waktu yang lama dalam melakukan audit. Hal itu dapat meminimalisir terjadinya audit delay. Penelitian Praptika dan Rasmini (2016) menyimpulkan bahwa tenur audit memiliki pengaruh signifikan terhadap audit delay dengan arah negatif.

Opini audit merupakan simpulan dari proses audit yang dilakukan auditor independen atas laporan keuangan perusahaan klien mengenai kewajaran laporan keuangan yang dibuat oleh manajemen dalam semua hal yang material sesuai prinsip akuntansi yang berterima umum (Rustiarni dan Sugiarti, 2013). Opini audit dapat mempengaruhi audit delay. Auditor akan membutuhkan waktu yang lebih lama dalam memahami dan mencari bukti audit sebagai landasan dalam memberikan opini audit selain unqualified opinion. Penelitian Aryaningsih dan Budiartha (2014) menyatakan bahwa opini audit berpengaruh terhadap audit delay. Ukuran perusahaan merupakan salah satu faktor yang mempengaruhi audit delay. Fodio et al. (2015) menyatakan bahwa perusahaan besar akan melaporkan hasil laporan keuangan yang telah diaudit semakin cepat karena perusahaan memiliki banyak 
sumber informasi dan memiliki sistem pengendalian internal perusahaan yang baik sehingga dapat mengurangi tingkat kesalahan dalam penyusunan laporan keuangan yang memudahkan auditor dalam melakukan audit laporan keuangan. Hal ini sejalan dengan pendapat Dyer dan Mc Hugh (1975) yang menyatakan bahwa perusahaan besar lebih konsisten untuk tepat waktu dibandingkan perusahaan kecil dalam menginformasikan laporan keuangannya. Ukuran perusahaan dilihat dari nilai aktiva perusahaan. Semakin besar nilai aktiva perusahaan maka semakin pendek audit delay dan sebaliknya. Hasil penelitian sebelumnya yang dilakukan oleh Putu Yulia dan Ni Ketut (2016), I Gede Wahyu dan Ni Made Dwi Ratnadi (2017), Komang Mariani dan Made Yenni (2016), Ni Wayan R. dan Ni Wayan MS (2013), Ni Nengah DA dan I Ketut Budhiarta (2014), Anthusian Indra K dan Herry Laksito (2015), Nabila C. dan Dini Wahjoe H (2018), Andi Kartika (2011), Nur Asni dkk (2017), Rediyanto dkk (2017), Ibadin Lawrence A dan Afensimi Elijah (2015) memberikan hasil yang tidak konsisten.

\section{TINJAUAN PUSTAKA DAN PENGEMBANGAN HIPOTESIS Laporan Keuangan}

Menurut Ikatan Akuntan Indonesia dalam PSAK (2017) laporan keuangan adalah suatu penyajian terstruktur dari posisi keuangan dan kinerja keuangan suatu entitas. Tujuan laporan keuangan adalah untuk memberikan informasi mengenai posisi keuangan, kinerja keuangan, dan arus kas entitas yang bermanfaat bagi sebagian besar pengguna laporan keuangan dalam pembuatan keputusan ekonomi. Laporan keuangan juga menunjukkan hasil pertanggungjawaban manajemen atas penggunaan sumber daya yang dipercayakan kepada mereka. Laporan keuangan menyajikan informasi mengenai entitas yang meliputi: aset, liabilitas, ekuitas, penghasilan dan beban termasuk keuntungan dan kerugian, kontribusi dari dan distribusi kepada pemilik dalam kapasitasnya sebagai pemilik, dan arus kas.

Komponen laporan keuangan lengkap terdiri dari (PSAK, 2017) :

a. Laporan posisi keuangan pada akhir periode;

b. Laporan laba rugi komprehensif selama periode;

c. Laporan perubahan ekuitas selama periode;

d. Laporan arus kas selama periode;

e. Catatan atas laporan keuangan;

f. Laporan posisi keuangan pada awal periode komparatif yang disajikan saat emiten atau perusahaan publik menerapkan suatu kebijakan akuntansi secara retrospektif atau membuat penyajian kembali pos-pos laporan keuangan atau ketika emiten atau perusahaan publik mengklasifikasi pos-pos dalam laporan keuangannya.

\section{Auditing}

Menurut Arens et.al (2014:24) auditing adalah akumulasi dan evaluasi bukti tentang informasi untuk menentukan dan melaporkan tingkat korespondensi antara informasi dan kriteria yang ditetapkan. Audit harus dilakukan oleh orang yang kompeten dan independen. Untuk melakukan audit, harus tersedia informasi dalam bentuk yang dapat diverifikasi dan beberapa standar (kriteria) yang dapat digunakan oleh auditor untuk mengevaluasi informasi tersebut, yang dapat dan memang memiliki banyak bentuk.

Dalam SPAP 2011 (PSA No. 29 SA Seksi 508 butir 10) terdapat lima tipe pendapat auditor, yaitu pendapat wajar tanpa pengecualian, pendapat wajar tanpa pengecualian 
dengan bahasa penjelasan, pendapat wajar dengan pengecualian, pernyataan tidak wajar, dan pernyataan tidak memberikan pendapat.

\section{Audit Delay}

Audit delay adalah senjang waktu audit, yaitu waktu yang dibutuhkan oleh auditor untuk menghasilkan laporan audit atas kinerja laporan keuangan suatu perusahaan. Rentang waktu penyelesaian audit oleh auditor terlihat dari perbedaan waktu antara tanggal laporan keuangan dengan tanggal opini audit dalam laporan keuangan auditan (Kurniawan dan Laksito, 2015). Disebutkan pula oleh Praptika dan Rasmini (2016) Audit delay adalah rentang waktu antara tanggal penutupan tahun buku dan tanggal laporan audit. Aryaningsih dan Budiartha (2014) mengatakanbahwa pentingnya Audit delay suatu laporan keuangan menuntut auditor agar menyelesaikan pekerjaan lapangannya secara tepat waktu. Disisi lain, pengauditan membutuhkan waktu yang cukup dalam mengidentifikasi masalahmasalah yang terjadi dalam perusahaan serta membutuhkan suatu ketelitian dalam menemukan bukti-bukti audit.

Otoritas Jasa Keuangan (OJK) mengeluarkan peraturan Nomor 29/POJK.04/2016 tentang laporan tahunan emiten atau perusahaan publik. Pada pasal 7 ayat (1) disampaikan bahwa emiten atau perusahaan publik wajib menyampaikan laporan tahunan kepada OJK paling lambat pada akhir bulan keempat (120 hari) setelah tahun buku berakhir. Pada peraturan tersebut, disebutkan juga sanksi-sanksi yang diberlakukan apabila sebuah perusahaan mengalami Audit delay yaitu peringatan tertulis, denda untuk membayar sejumlah uang tertentu, pembatasan kegiatan usaha, pembekuan kegiatan usaha, pencabutan izin usaha, pembatalan persetujuan, dan pembatalan pendaftaran.

\section{Tenur Audit}

Tenur audit adalah jangka waktu sebuah kantor akuntan publik melakukan perikatan terhadap kliennya dalam memberikan jasa audit laporan keuangan (Praptika dan Rasmini, 2016). Masa perikatan antara klien dengan sebuah KAP paling lama dilakukan selama enam tahun buku berturut-turut dan dilakukan oleh seorang auditor yang sama untuk tiga tahun buku berturut-turut. Auditor yang sudah lama melakukan audit pada sebuah perusahaan sudah memahami karakteristik perusahaan dengan baik, dan auditor dapat dengan mudah merancang program audit sehingga auditor tidak membutuhkan waktu yang lama dalam melakukan audit. Tenur audit yang lebih panjang akan meningkatkan efisiensi audit, sehingga membuat audit delay perusahaan menjadi pendek.

Hasil penelitian Praptika dan Rasmini (2016) yang mengatakan bahwa Tenur audit memiliki pengaruh signifikan terhadap audit delay dengan arah negatif. Hal ini bisa disebabkan karena setiap KAP akan memberikan jasa yang baik untuk kliennya sehingga lama atau tidaknya keterikatan KAP terhadap kliennya tidak mempengaruhi audit delay. Hasil penelitian Krisnanda dan Ratnadi (2017), Nur Asni, dkk (2017), Komang Mariani dan Made Yenni Latrini (2016), menyatakan bahwa semakin panjang masa perikatan KAP atau semakin jarang suatu perusahaan mengganti jasa KAP yang digunakan, maka akan mengakibatkan kecepatan publikasi laporan keuangan tahunan perusahaan. sedangkan hasil penelitian Mariani, Komang dan Made Yenny Latrini (2016) menyatakan tenur audit berpengaruh positif terhadap audit delay.

$\mathrm{H} 1$ : Tenur audit berpengaruh terhadap audit delay

\section{Opini Audit}


Opini audit merupakan simpulan dari proses audit yang dilakukan auditor bebas atas laporan keuangan perusahaan klien mengenai kewajaran laporan keuangan yang dibuat oleh manajemen dalam semua hal yang material sesuai prinsip akuntansi yang berterima umum. Opini audit atas laporan keuangan perusahaan menjadi tolok ukur para penggunanya dalam mengambil keputusan. Opini audit merupakan pendapat yang diluarkan oleh auditor independen atas kewajaran suatu laporan keuangan. Opini audit digunakan oleh pengguna intern dan ekstern laporan keuangan untuk mengetahui kinerja perusahaan selama periode tertentu sehingga dapat digunakan sebagai dasar pengambilan keputusan (Rustiarini dan Sugiarti, 2013).

Opini selain wajar tanpa pengecualian (unqualified opinion) merupakan opini yang tidak diharapkan oleh manajemen perusahaan. Mumpuni (2011) menyatakan bahwa perusahaan yang menerima pendapat selain unqualified opinion membutuhkan waktu audit yang lebih lama daripada perusahaan yang mendapatkan unqualified opinion. Hal ini terjadi karena pemberian pendapat selain unqualified opinion memerlukan negosisasi dengan klien serta konsultasi dengan patner audit. Selain itu, auditor juga dituntut untuk menemukan penyimpangan dan disertai dengan bukti-bukti yang dapat mendukung temuannya. Hal ini sejalan dengan penelitian yang dilakukan Nengah Ni Devi Aryaningsih dan I Ketut Budhiarta (2014) yang menyatakan bahwa opini auditor berpengaruh negatif terhadap audit delay, karena ketika perusahaan mendapat opini selain wajar tanpa pengecualian maka auditor akan mencari bukti-bukti penyebab dikeluarkannya opini selain wajar tanpa pengecualian. Pencarian bukti-bukti serta temuan audit akan memakan banyak waktu sehingga mengindikasikan terjadinya audit delay. Sedangkan hasil penelitian Wayan $\mathrm{Ni}$ Rustiarini dan Ni Wayan Mita Sugiarti (2013) menyatakan Tenure Audit tidak berpengaruh terhadap audit delay.

$\mathrm{H} 2$ : Opini audit berpengaruh terhadap audit delay

\section{Ukuran Perusahaan}

Ukuran perusahaan adalah besar kecilnya suatu perusahaan yang dilihat dari besarnya aset yang dimiliki oleh perusahaan. Fodio et al. (2015) menyatakan bahwa perusahaan besar akan melaporkan hasil laporan keuangan yang telah diaudit lebih cepat karena perusahaan memiliki banyak sumber informasi dan memiliki sistem pengendalian internal perusahaan yang baik sehingga dapat mengurangi tingkat kesalahan dalam penyusunan laporan keuangan yang memudahkan auditor dalam melakukan audit laporan keuangan. Hal ini sejalan dengan pendapat Dyer dan Mc Hugh (1975) dalam Kartika (2009), yang menyatakan bahwa perusahaan besar lebih konsisten untuk tepat waktu dibandingkan perusahaan kecil dalam menginformasikan laporan keuangannya. Hasil penelitian Kartika, Andi (2011), Indra, Anthusian Kurniawan dan Herry Laksito (2015), Sa'adah, Shohelma (2013) menyatakan bahwa ukuran perusahaan berpengaruh negatif terhadap audit delay. Sedangkan hasil penelitian Nengah, Ni Devi Aryaningsih dan I Ketut Budiartha (2014) menyatakan ukuran perusahaan yang diukur dengan total asset tidak berpengaruh terhadap audit delay.

H3 : Ukuran Perusahaan berpengaruh terhadap audit delay

\section{METODE PENELITIAN}

Penelitian ini menggunakan metode verifikatif untuk mengetahui ada tidaknya pengaruh tenur audit, opini audit dan ukuran perusahaan terhadap audit delay pada perusahaan sektor manufaktur yang terdapat di Bursa Efek Indonesia tahun 2016-2018. Pemilihan sektor manufaktur karena perusahaan yang mengalami masalah keterlambatan penyampaian laporan keuangan paling banyak terjadi di sektor manufaktur. Sedangkan 
pemilihan tahun pengamatan 2016 sampai dengan 2018 dengan pertimbangan tiga tahun terakhir periode terbaru pada saat penelitian dilakukan. Data yang digunakan adalah data sekunder yang dikumpulkan dengan metode dokumentasi melalui situs www.idx.co.id.

\section{Populasi dan sampel}

Populasi dalam penelitian ini adalah perusahaan manufaktur yang terdaftar di Bursa Efek Indonesia mengalami audit delay. Jumlah populasi sebanyak 108 perusahaan. Dalam pengumpulan sampel peneliti menggunkana teknik purpose sampling.

\section{Operasional Variabel}

Variabel dalam penelitian ini terdiri dari:

1. Variabel bebas

a. Tenur audit adalah jangka waktu sebuah kantor akuntan publik melakukan perikatan terhadap kliennya dalam memberikan jasa audit laporan keuangan (Praptika dan Rasmini, 2016). Pengukuran tenur audit menggunakan indikator $1,2,3$ dan seterusnya. Apabila suatu perusahaan diaudit dengan auditor baru maka diberi nilai 1, dan apabila ditahun berikutnya masih dengan auditor yang sama maka akan diberi nilai 2, 3 dan seterusnya.

b. Opini audit merupakan simpulan dari proses audit yang dilakukan auditor bebas atas laporan keuangan perusahaan klien mengenai kewajaran laporan keuangan yang dibuat oleh manajemen dalam semua hal yang material sesuai prinsip akuntansi yang berterima umum (Rustiarini dan Sugiarti, 2013). Variabel opini audit diproksikan dengan variabel dummy. Jika perusahaan mendapatkan opini wajar tanpa pengecualian maka diberikan nilai 1 , dan jika perusahaan mendapatkan opini selain wajar tanpa pengecualian maka akan diberi nilai 0 .

c. Ukuran perusahaan adalah besar kecilnya suatu perusahaan yang dilihat dari besarnya aset yang dimiliki oleh perusahaan tersebut.

\section{Variabel Terikat}

Audit delay adalah senjang waktu audit, yaitu waktu yang dibutuhkan oleh auditor untuk menghasilkan laporan audit atas kinerja laporan keuangan suatu perusahaan. Rentang waktu penyelesaian audit oleh auditor terlihat dari perbedaan waktu antara tanggal laporan keuangan dengan tanggal opini audit dalam laporan keuangan auditan (Kurniawan dan Laksito, 2015). Variabel audit delay merupakan selisih tanggal laporan keuangan diaudit dengan tanggal laporan keuangan tutup buku.

\section{Teknik Analisis Data}

Sebelum dilakukan uji hipotesis akan dilakukan uji asumsi klasik terlebih dahulu yang terdiri dari uji normalitas, multikolonieritas, heteroskedastisitas, dan autokorelasi. Kemudian dilakukan uji hipotesis dengan uji statistis F dan uji t.

Uji Statistik Simultan

Uji signifikansi terhadap tenur audit, opini audit dan ukuran perusahan secara bersamaan (simultan) dilakukan dengan uji F. Langkah-langkah dalam melakukan uji F adalah:

a. Merumuskan Hipotesis

a. $\mathrm{H}_{0}$ : Tenur audit, opini audit dan ukuran perusahaan secara simultan tidak berpengaruh terhadap audit delay

b. $\mathrm{H}_{\mathrm{a}}$ : Tenur audit, opini audit dan ukuran perusahaan secara simultan berpengaruh terhadap audit delay 
b. Menghitung Nilai $F_{\text {hitung }}$ nilai $F_{\text {tabel }}$

Uji $F_{\text {hitung }}$ dapat dihitung dengan menggunakan rumus sebagai berikut:

$$
\begin{array}{l|l|}
\cline { 2 - 2 } & \multicolumn{1}{|c|}{F=\frac{R^{2} / k}{\left(1-R^{2}\right) /(n-k-1)}} \\
& \\
\text { Keterangan: } & : \text { Fhitung } \\
\mathrm{F} & \text { : Koefisien korelasi yang telah ditentukan } \\
\mathrm{R}^{2} & \text { : Jumlah variabel bebas } \\
\mathrm{k} & \text { : Jumlah anggota sampel } \\
\mathrm{n} &
\end{array}
$$

c. Kriteria Penerimaan atau Penolakan Hipotesis

a. Hipotesis di atas akan diuji berdasarkan daerah penerimaan dan daerah penolakan dengan taraf signifikansi yang digunakan adalah $\alpha=0,05$ yang ditetapkan sebagai berikut:

i. Jika sig $>0,05$ atau $\mathrm{F}_{\text {hitung }}<\mathrm{F}_{\text {tabel }}$ maka $\mathrm{H}_{0}$ diterima.

ii. Jika sig $<0,05$ atau $\mathrm{F}_{\text {hitung }}>\mathrm{F}_{\text {tabel }}$ maka $\mathrm{H}_{0}$ ditolak.

\section{Uji Statistik (Parsial)}

Uji statistik t untuk menunjukan seberapa jauh pengaruh variabel bebas secara individual dalam menerangkan variabel terikat (Ghozali, 2016). Langkah-langkah dalam melakukan uji t adalah:

a. Merumuskan Hipotesis

Pengaruh tenure audit terhadap audit delay

$\mathrm{H}_{0}$ : Tenur audit tidak berpengaruh signifikan terhadap audit delay

$\mathrm{H}_{\mathrm{a}}$ : Tenur audit berpengaruh signifikan terhadap audit delay

Pengaruh opini audit terhadap audit delay

$\mathrm{H}_{0}$ : Opini audit tidak berpengaruh signifikan terhadap audit delay

$\mathrm{H}_{\mathrm{a}}$ : Opini audit berpengaruh signifikan terhadap audit delay

Pengaruh ukuran perusahaan terhadap audit delay

$\mathrm{H}_{0}$ : Ukuran perusahaan tidak berpengaruh signifikan terhadap audit delay

$\mathrm{H}_{\mathrm{a}}$ : Ukuran perusahaan berpengaruh signifikan terhadap audit delay

b. Menghitung Nilai $t_{\text {hitung }}$ dan nilai $t_{\text {tabel }}$

Perhitungan Nilai $t_{\text {hitung }}$ dengan menggunakan rumus sebagai berikut:

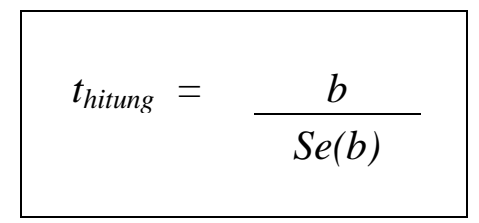

Keterangan:

$b \quad$ : Koefisien regresi ganda 


\section{$\mathrm{Se}(b) \quad$ : Standar error}

Sedangkan Nilai $t_{\text {tabel }}$ bergantung pada besarnya derajat bebas $(\mathrm{db})$ atau degree of freedom (df) dan tingkat signifikansi yang digunakan. Derajat bebas (db) dapat dihitung dengan rumus sebagai berikut:

$$
\mathrm{db}=\mathrm{n}-\mathrm{k}-1
$$

Keterangan:

$\mathrm{db} \quad$ : derajat bebas

n : jumlah data observasi

$\mathrm{k} \quad$ : variabel bebas yang digunakan

c. Kriteria Penerimaan atau Penolakan Hipotesis

Hipotesis di atas akan diuji berdasarkan daerah penerimaan dan daerah penolakan dengan taraf signifikansi yang digunakan adalah $\alpha=0,05$ yang ditetapkan sebagai berikut:

a. Jika sig $<0,05$ atau $t_{\text {hitung }}>t_{\text {tabel }}$ maka variabel $X$ secara parsial memiliki pengaruh yang signifikan terhadap variabel $\mathrm{Y}$.

b. Jika sig $>0,05$ atau $t_{\text {hitung }}<t_{\text {tabel }}$ maka variabel $X$ secara parsial tidak memiliki pengaruh yang signifikan terhadap variabel $\mathrm{Y}$.

\section{HASIL DAN PEMBAHASAN}

\section{Analisis Statistik deskriptif}

Hasil statistik deskriptif disajikan pada tabel 1 berikut.

Tabel 1

Statistik Deskriptif

\begin{tabular}{llll}
\hline \multicolumn{1}{c}{ Variabel } & \multicolumn{1}{c}{ Nilai Maksimum } & \multicolumn{1}{c}{ Nilai Minimum } & \multicolumn{1}{c}{ Nilai Rata-rata } \\
\hline Tenur Audit & 3.00 & 1.00 & 1,658824 \\
Opini Audit & 1.00 & 0.00 & 0,870588 \\
Ukuran Perusahaan & Rp. 126.723 .419 .253 .000 & Rp. 98.190 .640 .839 & 11.767 .308 .249 .014 \\
Audit delay & 65.00 & 395.00 & 97,16471 \\
\hline
\end{tabular}

Sumber: Hasil Pengolahan Data

Berdasarkan tabel 1menunjukkan bahwa:

1. Nilai tenur audit tertinggi adalah 3 dan nilai terendah adalah 1 . Nilai tertinggi 3 , artinya selama periode 2016-2018 perusahaan manufaktur yang menjadi sampel memiliki periode keterlibatan dengan auditor yang sama selama 3 tahun. Nilai terendah 1, artinya selama periode 2016-2018 perusahaan manufaktur terlibat dalam periode keterlibatan dengan auditor selama 1 tahun atau dengan kata lain perusahaan melakukan perubahan auditor setiap tahun. Dari 85 perusahaan sampel, 20 perusahaan $(23,53 \%)$ menggunakan auditor yang sama selama 3 tahun berturut-turut, dan 16 perusahaan $(18,82 \%)$ menggunakan auditor yang sama selama 2 tahun dan 49 perusahaan $(57,65 \%)$ menggunakan auditor baru. 
2. Perusahaan sampel yang menerima opini audit wajar tanpa pengecualian adalah 74 perusahaan $(87 \%)$ dan sisanya 11 perusahaan $(13 \%)$ menerima pendapat selain wajar tanpa pengecualian.

3. Nilai aset tertinggi Rp. 126.723.419.253.000 dimiliki oleh PT. Indah Kiat Pulp \& Paper, Tbk., dan nilai aset terendah Rp. 98.190.640.839 dimiliki oleh PT. Primarindo Asia Infrastructure, dan nilai aset rata-rata adalah Rp 11.767.308.249.014

4. Nilai audit delay tertinggi adalah 395 hari terjadi di PT. Tiga Pilar Tbk dan nilai audit delay terendah adalah 65 hari di PT. Toba Pulp Lestari Tbk. Perusahaan ratarata menyerahkan hasil laporan keuangan yang diaudit selama 97 hari.

\section{Analisis Data}

\section{Uji Asumsi Klasik}

Hasil uji asumsi klasik menunjukkan bahwa semua uji terpenuhi dengan penjelasan sebagai berikut: Uji normalitas dengan One Sample Kolmogorov Smirnov, menunjukkan data terdistribusi normal dengan nilai signifikansi 0.068 (> 0.05). Hasil pengujian mengindikasikan tidak terjadi multikolinearitas karena nilai nilai variance inflation factor (VIF) dari variabel bebas kurang dari 10 dan nilai tolerance lebih dari 0.1. Tidak terjadi autokorelasi yang diindikasikan dari nilai dU $(1,721)<\mathrm{DW}(1,971)<4$ - dU (2,279). Tidak terjadi heteroskedastisitas yang diindikasikan dari nilai signifikansi hasil uji park lebih dari 0,05 .

\section{Koefesien Korelasi dan Koefesien determinasi}

Nilai koefesien korelasi berada di angka 0,447 (44,70\%) menujukkan terdapat hubungan yang rendah antara variabel bebas (tenure audit, opini audit, dan ukuran perusahaan) dengan variabel terikat (audit delay). Dan nilai koefesien determinasi sebesar $19,90 \%$, mengandung makna bahwa variabel bebas mempengaruhi variabel terikat dengan kontribusi $19,90 \%$, dan sisanya $80,10 \%$ dipengaruhi oleh variabel lain yang tidak diteliti dalam penelitian ini.

Tabel 1. Hasil Perhitungan Koefesien Korelasi dan Determinasi

\begin{tabular}{ccc}
\hline $\mathrm{R}$ & R Square & Adjusted R Square \\
\hline, 447 & 0,199 & 0,170 \\
\hline
\end{tabular}

Sumber : Hasil Pengolahan Data

\section{Uji Hipotesis}

\section{Uji Simultan ( Uji F)}

Hasil uji simultan pada tabel 2 menunjukkan bahwa nilai $\mathrm{F}$ hitung sebesar 6,727 lebih besar dari nilai $F$ tabel 2,72 dan nilai signifikansi 0.000 lebih kecil dari 0.05 ,sehingga disimpulkan bahwa Ho ditolak. Hal ini mengandung makna bahwa variabel tenur audit, opini audit and ukuran perusahaan berpengaruh signifikan terhadap audit delay pada perusahaan manufaktur yang terdaftar di Bursa Efek Indonesia tahun 2016-2018.

Tabel 2 Hasil Uji F

\begin{tabular}{lllllll}
\hline Model & Sum of Squares & df & Mean Square & F & Sig. \\
\hline
\end{tabular}




\begin{tabular}{llllll}
\hline Regression & 0,097 & 3 & 0,032 & 6,727 & .000 \\
Residual & 0,388 & 81 & 0,005 & & \\
Total & 0,485 & 84 & & & \\
\hline
\end{tabular}

Sumber : Hasil Pengolahan Data

Hasil penelitian ini menunjukkan bahwa terjadinya audit delay pada perusahaan manufaktur yang terdaftar di BEI tahun 2016-2018 dipengaruhi oleh masa kerja audit (tenur audit), opini audit dan ukuran perusahaan. Perusahaan menggunakan auditor yang sama dengan periode sebelumnya, memperoleh opini wajar tanpa pengecualian dan memiliki ukuran perusahaan yang relatif besar akan cenderung memperpendek masa audit delay. Dengan kata lain perusahaan memiliki peluang untuk menyampaikan laporan keuangan yang sudah diaudit tepat waktu. Dan sebaliknya, jika perusahaan menggunakan auditor yang berbeda dengan periode sebelumnya, memperoleh opini selain wajar tanpa pengecualian dan memmiliki ukuran perusahaan yang relative kecil, maka kemungkinan audit delay akan lebih panjang.

\section{Uji Parsial (Uji t)}

Berdasarkan hasil uji t yang disajikan pada tabel 3, menunjukkan bahwa nilai t hitung untuk tenur audit (X1) adalah -2,018 dan opini audit (X2) adalah -3,972. Nilai t hitung untuk variabel tenur audit dan opini audit lebih kecil dari nilai t tabel sebesar 1,66298. Selain itu nilai signifikansi variabel tenur audit dan opini audit lebih kecil dari 0,05. Hasil pengujian variabel tenur audit dan opini audit menyimpulkan Ho ditolak yang artinya tenur audit dan opini audit secara parsial memiliki pengaruh signifikan terhadap audit delay dengan arah hubungan negatif. Sedangkan nilai t hitung variabel ukuran perusahaan sebesar -0,659 lebih kecil dari t tabel -1,66298. Hasil pengujian untuk variabel ukuran perusahaan menyimpulkan bahwa Ho diterima, artinya ukuran perusahaan tidak berpengaruh signifikan terhadap audit delay.

Tabel 3. Hasil Uji t

Coefficients $^{\mathrm{a}}$

\begin{tabular}{|c|c|c|c|c|c|}
\hline \multirow{2}{*}{ Model } & \multicolumn{2}{|c|}{$\begin{array}{c}\text { Unstandardized } \\
\text { Coefficients }\end{array}$} & \multirow{2}{*}{$\begin{array}{c}\text { Standardized } \\
\text { Coefficients } \\
\text { Beta }\end{array}$} & \multirow{2}{*}{$\mathrm{t}$} & \multirow{2}{*}{ Sig. } \\
\hline & B & $\begin{array}{l}\text { Std. } \\
\text { Error }\end{array}$ & & & \\
\hline (Constant) & 2,127 & 0,131 & & 16,258 & 0,000 \\
\hline Tenur Audit & $-0,031$ & 0,015 & $-0,202$ & $-2,018$ & 0,047 \\
\hline Opini Audit & $-0,111$ & 0,028 & $-0,403$ & $-3,972$ & 0,000 \\
\hline $\begin{array}{l}\text { Ukuran } \\
\text { Perusahaan }\end{array}$ & $-0,007$ & 0,011 & $-0,067$ & $-0,659$ & 0,512 \\
\hline
\end{tabular}

Sumber : Hasil Pengolahan Data

Auditor yang telah melakukan audit dalam waktu lama di perusahaan atau pernah melakukan audit pada periode sebelumnya akan dapat dengan mudah memahami karakteristik dan merancang program audit dengan benar. Auditor tidak perlu waktu lama dalam melakukan audit, sehingga mereka dapat menyelesaikan proses audit lebih cepat dan atau meminimalkan penundaan audit. Hasil penelitian ini sejalan dengan hasil penelitian Krisnanda dan Ratnadi (2017) yang menyatakan bahwa semakin lama masa pertunangan Kantor Akuntan Publik, semakin tinggi publikasi laporan keuangan tahunan perusahaan. 
Hasil penelitian ini juga mendukung hasil penelitian Wayan Ni Rustiarini dan Ni Wayan Mita Sugiarti (2013), Mariani Komang dan Made Yenni Latrini (2016), Asni Nur dkk (2017).

Ketentuan opini wajar tanpa pengecualian diharapkan dapat meminimalkan terjadinya audit delay, karena auditor tidak perlu menemukan banyak bukti dan temuan audit yang ditemukan relatif sedikit. Hal ini sejalan dengan penelitian yang dilakukan oleh Aryaningsih dan Budiartha (2014) yang menyatakan bahwa opini auditor berpengaruh negatif terhadap audit delay, karena ketika suatu perusahaan mendapat opini selain tidak memenuhi syarat, auditor akan mencari bukti yang menyebabkan opini menjadi dikeluarkan selain tidak memenuhi syarat. Pencarian untuk bukti dan temuan audit akan memakan banyak waktu, menunjukkan penundaan audit. Hasil penelitian ini mendukung hasil penelitian sebelumnya yang dilakukan oleh Nengah Ni Devi Aryaningsih dan I Ketut Budiartha (2014), Indra Anthusian Kurniawan dan Herry Laksito (2015), Chaerinisa Nabila dan Dini Wahjoe Hapsari (2018).

Dalam penelitian ini, ukuran perusahaan tidak memiliki pengaruh yang signifikan terhadap audit delay. Hal ini dapat terjadi karena proses pelaksanaan audit laporan keuangan tidak dipengaruhi oleh jumlah aset yang dimiliki oleh perusahaan. Meskipun perusahaan memiliki aset besar, tetapi jika didukung oleh sistem kontrol internal yang baik dan kepatuhan dengan standar akuntansi yang berlaku, proses audit dapat diselesaikan lebih cepat, sehingga tidak terjadi penundaan audit. Hasil penelitian ini sejalan dengan penelitian Anak Agung \& Widhiyani (2016), Vicky \& Wilopo (2016), dan Nengah Ni Devi Aryaningsih dan I Ketut Budiartha (2014) yang menyatakan bahwa ukuran perusahaan tidak berpengaruh signifikan terhadap penundaan audit.

\section{KESIMPULAN}

Berdasarkan hasil dan pembahasan dapat diambil kesimpulan sebagai berikut: Tenur audit, opini audit dan ukuran perusahaan secara simultan berpengaruh signifikan terhadap audit delay. Tenur audit dan opini audit secara parsial berpengaruh signifikan terhadap audit delay dengan arah hubungan negatif. Hasil ini mengindikasikan bahwa semakin panjang tenur audit akan memperpendek audit delay dan adanya opini audit wajar tanpa pengecualian juga akan memperpendek audit delay sedangkan ukuran perusahaan tidak berpengaruh signifikan terhadap audit delay.

\section{DAFTAR PUSTAKA}

Ahmed, Alim A. A \& Hossain, M. S. 2010. Audit Report Lag: A Study of the Bangladeshi Listed Companies. ASA University Review 4 (2): 49-56.

Amani dan Waluyo. 2016. Pengaruh Ukuran Perusahaan, Profitabilitas, Opini Audit dan Umur Perusahaan terhadap Audit delay. Jurnal Nominal, Vol. V, No. 1, Hal. 135150.

Andi Kartika. (2011). Faktor-Faktor yang Mempengaruhi Audit delay pada Perusahaan Manufaktur yang Terdaftar di BEI. Dinamika Keuangan dan Perbankan Universitas Stikubank 3.2, 152-171.

Anthusian, Indra Kurniawan \& Herry Laksito. (2015). Analisis Faktor-Faktor yang Mempengaruhi Audit delay pada Perusahaan LQ 45. Diponegoro Journal of Accounting 4.3, 1-13. 
Arens, Alvin A, Rendal J, Elder \& Mark S. Beasley. (2014), Auditing dan Jasa Assurance (terjemahan). Edisi kelimabelas. Jakarta: Erlangga.

Asni, Nur dkk. (2017). The Influence of Educational Background, Auditor Tenure, and Auditor Professional Proficiency to Audit delay. International Journal of Management and Applied Science Halu Oleo University 3.2, 2394-7926.

BAPEPAM. 2011. Keputusan Ketua Badan Pengawas Pasar Modal dan Lembaga Keuangan Nomor: KEP-346/BL/2011 Peraturan nomor X.K.2 Tentang Penyampaian Laporan Keuangan.

Carslaw,C.A.P.N.danS.E.Kaplan.(1991).AnExaminationofAuditDelay:FurtherEvidencefrom NewZealand.Accounting andBusiness Research, 22(85):21-32

Dyer, J. C. I. V., dan A. J. McHugh. 1975. The Timeliness of The Australian Annual Report. Journal of Accounting Research. Autumn. Vol. 13. o.2. Hal: 204- 219.

Ervilah, dan Fachriyah, N. 2015. Faktor-faktor yang Mempengaruhi Audit delay. Jurusan Akuntansi Fakultas Ekonomi dan Bisnis Universitas Brawijaya Malang.

Ettredge, Michael, Chan Li, And Lili Sun. 2006. The Impact Internal Control Quality On Audit delay In The Sox Era. Auditing: A Journal Of Practice and Theory.

Fodio, Musa Inuwa, Victor Chiedu Oba, Abiodun Bamidele Olukoju and Ahmed Abubakar Zik-rullahi. 2015. IFRS Adoption, Firm Traits and Audit Timeliness: Evidence from Nigeria. Jurnal Acta Universitatis Danubius. 11(3), pp:126-139.

Halim, Varianada (2000). Faktor-faktor yang Mempengaruhi Audit delay: Studi Empiris pada Perusahaan-perusahaan di Bursa Efek Jakarta. Jurnal Bisnis dan Akuntansi. Vol. 2, No. 1, p. 63-75.

I Gede Wahyu Krisnanda \& Ni Made Dwi Ratnadi. (2017). Pengaruh Financial Distress, Umur Perusahaan, Tenure Audit, Kompetensi Dewan Komisarispada Kecepatan Publikasi Laporan Keuangan. E-Jurnal Akuntansi Universitas Udayana 20.3, 1933-1960.

Ibadin Lawrence Ayemere and Afensimi Elijah. (2015). Corporate Attributes and Audit delay in Emerging Markets: Empirical Evidence from Nigeria. International Journal of Business and Social Research 5.3.

Ikatan Akuntan Indonesia. (2017), Standar Akuntansi Keuangan, Jakarta: Ikatan Akuntan Indonesia

Ikatan Akuntansi Indonesia (IAI). 2011.standar Profesional Akuntan Publik 31 Maret 2011. Jakarta: Salemba Empat.

Kartika, Andi. 2009. Faktor-faktor yang Mempengaruhi Audit delay di Indonesia. Journal Bisnis dan Ekonomi. Maret 2009. Vol. 16. No 1: hlm 1-17.

Mardiana, et al. (2015). Pengaruh Ukuran Perusahaan, Holding Company, dan Ukuran Kantor Akuntan Publik terhadap Audit delay (Studi Empiris pada Perusahaan Manufaktur yang Terdaftar di Bursa Efek Indonesia Tahun 2011-2013). Prosiding Akuntansi. ISSN: 2460-6561.

Meylisa Januar Iskandar dan Estralita Trisnawati. 2010. Faktor -Faktor Yang Mempengaruhi Audit Report Lag Pada Perusahaan Yang Terdaftar di Bursa Efek Indonesia. Jurnal Bisnis dan Akuntansi Vol. 12 No.3, Desember 2010 Hlm 175-186.

Mumpuni,R.(2011).AnalisisFaktor-faktor yang Mempengaruhi Audit delay padaPerusahaan Non Keuangan di Bursa Efek Indonesia Tahun 2006-2008.

Nasser et. al. 2006. Auditor-Clients Relationship: The Case of Tenure Audit and Auditor Switching in Malaysia. Managerial Auditing Journal SpecialIssue, Vol.21 (7), pp. 724-737. 
Ni Nengah Devi Aryaningsih \& I Ketut Budiartha. (2014). Pengaruh Total Aset, Tingkat Solvabilitas dan Opini Audit pada Audit delay. E-JurnalAkuntansi UniversitasUdayana 7.3, 747-647.

Ni Wayan Rustiarini \& Ni Wayan Mita Sugiarti. (2013). Pengaruh Karakteristik Auditor, Opini Audit, Tenure Audit, Pergantian Auditor pada Audit delay. Jurnal Ilmiah Akuntansi dan Humanika 2.2, 2089-3310.

Ningsaptiti, Restie. 2010. Analisis Pengaruh Ukuran Perusahaan Dan Mekanisme Corporate Governance Terhadap Manajemen Laba (Studi Empiris Pada Perusahaan Manufaktur Yang Terdaftar Pada Bursa Efek Indonesia 20062008).Skripsi.Fakultas Ekonomi Universitas Malang.

Ningsih, Ni Luh Sari Widhiyani. 2015. Pengaruh Ukuran Perusahaan, Laba Operasi, Solvabilitas, Dan Komite Audit Pada Audit delay. E-Jurnal Akuntansi Universitas Udayana 12.3 : 481-495, ISSN: 2302-8556.

Pawitri, N. M. P. Dan Yadnyana, K. (2015), Pengaruh Audit delay, Opini Audit, Reputasi auditor dan Pergantian Manajemen Pada Voluntary Auditor Switching. E-jurnal Akuntansi Universitas Udayana Vol.10 N0.1 Hlm 214-228.

Peraturan Otoritas Jasa Keuangan Nomor: 13/POJK.03/2017 Tentang Penggunaan Jasa Akuntan Publik dan Kantor Akuntan Publik dalam Kegiatan Jasa Keuangan.

Peraturan Otoritas Jasa Keuangan Nomor: 29/POJK.04/2016 Tentang Laporan Tahunan Emiten atau Perusahaan Publik.

Peraturan Pemerintah Republik Indonesia Nomor 20 Tahun 2015 Tentang Praktik Akuntan Publik.

Prahartari, F. A. (2013), Analisis Faktor-faktor yang Mempengaruhi Auditor Switching.( studi Empiris Pada Perusahaan Real Estate dan Properti yang Terdaftar di Bursa Efek Indonesia). Skripsi Fakultas Ekonomi dan Bisnis. Universitas Islam Negeri Syarif Hidayatullah Jakarta.

Praptika, Ni Ketut Rasmini, , Putu Yulia Hartanti. 2016. Pengaruh Tenure Audit, Pergantian Auditor Dan Financial Distress Pada Audit delay Pada Perusahaan Consumer Goods. E- Jurnal Akuntansi Universitas Udayana Vol.15.3. Juni (2016): 2052-2081.

Puspitasari, Dwi Ninda. 2016. Pengaruh Ukuran Perusahaan, Anak Perusahaan, Profitabilitas, Leverage, Dan Ukuran KAP Terhadap Audit delay (Pada Perusahaan Manufaktur Yang Terdaftar Di Bursa Efek Indonesia Periode 20122014). Universitas Muhammadiyah Surakarta Online Journals.h:3.

Putra, Rediyanto, Sutrisno, Endang Mardianti. (2017). Determinant of Audit delay: Evidance from Companies in Indonesia. International Journal of Business and Management Invention Brawijaya University 6.6, 12-21.

Putu Yulia \& Ni Ketut Rasmini. (2016). Pengaruh Tenure Audit, Pergantian Auditor danFinancial Distress pada Audit delay pada Perusahaan Consumer Goods. EJurnal Akuntansi Universitas Udayana 15.3, 2052-2081

Wayan, Ni Rustiarini, Ni Wayan Mitra Sugiarti (2013). Pengaruh Karakteristik Auditor, Opini Audit, Tenure Audit, Pergantian Auditor pada Audit delay. Jurnal Ilmiah Akuntansi dan Humanika.2(2).h:669-670.

Wiryakriyana, Ni Luh Sari Widhiyani, 2017. Pengaruh Ukuran Perusahaan, Leverage, Auditor Switching, Dan Sistem Pengendalian Internal Pada Audit delay. E-Jurnal Akuntansi Universitas Udayana Vol.19.1. April (2017): 771-798, ISSN: 23028556. 